Artem S. Lukyanetz ${ }^{1}$, Nguyen Canh Toan ${ }^{2}$, Elena E. Pismennaya ${ }^{3}$,

Sergei V. Ryazantsev ${ }^{4}$, Vladimir S. Tikunov ${ }^{*}$, Pham Hoang Hai6

1 Center for Social Demography and Economic Sociology (Institute for Socio-

Political Studies); Moscow, 119991, Leninskyi prospect, 32-a, Russia;

Tel +7 49953028 84, e-mail: artem_ispr@mail.ru

2 Institute for European Studies, VASS; Hanoi, Thanh Suan, Bui Siong Chak, 358/57B,

Vietnam; Tel: 8443537 0811, e-mail: okabc007@yahoo.com

3 Department of Theoretical Sociology, Financial University under the Government of the Russian Federation; Moscow, 125993, Leningradskyi prospect, 49, Russi;

Tel: +7 (499) 943-95-77, e-mail: nikitaR@list.ru

4 Center for Social Demography and Economic Sociology (Institute for Socio-

Political Studies);

Moscow, 119991, Leninskyi prospect, 32-a, Russia; Tel +7 49953028 84,

e-mail: riazan@mail.ru

5 Lomonosov Moscow State University, Faculty of Geography; Leninskie Gory,

Moscow, 119991, Russia; Tel: +7 495 9391339, e-mail: tikunov@geogr.msu.su

* Coresponding author

6Institute of Geography VAST; Hanoi, Fam Van Dong, 06/24, Vietnam;

tel: +084 4383612 02, e-mail: phhoanghai@yahoo.com

\title{
VIETNAMESE MIGRATION IN THE CONTEXT OF CLIMATE CHANGE
}

ABSTRACT. The paper examines emigration from Vietnam in the context of global climate change. Vietnam is among the five countries, most vulnerable to water level rise in the oceans associated with global warming. The areas of potential flooding include territories with most dense population and are extremity important for the economy of Vietnam. The country has a significant demographic potential exceeding $90 \mathrm{~m} / \mathrm{n}$ people. Vietnamese migration has a relatively long history. Large Vietnamese communities have grown in the countries of Eastern Europe; these communities are relatively well integrated into the host countries. Increase in global mean temperatures could lead to severe storms, tsunamis, and flooding and force significant portion of the population out of the Mekong Delta regions and Central provinces of Vietnam. The paper discusses the potential of Atlas Information Systems (AISs) for the assessment of social-economic and demographic consequences of climate change in Vietnam. The authors describe an AIS they are developing. This AIS consists of blocks that provide for a close link between socio-political, economic (production), natural resource, and environmental components for the integrated assessment of the provinces of Vietnam. Simulation of events shows that the flood zone could affect such populated provinces as An Giang, Kien Giang, Hau Giang, Dong Thap, Long An, Tien Giang, Vinh Long and Can Tho. To address this problem, the Vietnamese authorities, in 2008, approved the state target program to respond to climate change. The Ministry of Natural Resources and Environment was commissioned to create a scenario of climate change and sea level rise in Vietnam. However, the problem requires an immediate response at the international level, as the threat cannot be localized within the borders of Vietnam. Flooding may require mandatory relocation of the population in the country and, possibly, beyond its borders. If people are not relocated gradually, a reduction in the country's territory with high population density, considering the specifics of the settlement pattern and reproduction trends, could result in a significant migration flow of forced migrants - environmental 
refugees. The territory of Vietnam may not be sufficient to absorb the entire flow of immigrants and, as a result, the flow would be directed out of the country. However, if the resettlement program starts now in the form of organized labor migration, it may be possible to anticipate and mitigate the negative scenario. Besides, organized labor emigration would be even beneficial for Vietnam in the socio-economic respect. The paper suggests measures to improve Russia's migration policy aimed at attracting and using Vietnamese workers in a regulated way that would benefit Russia socially and economically.

KEY WORDS: Vietnam, emigration, global warming, Vietnamese communities in host countries, Atlas Information Systems, Eastern Europe, Russia, migration policy, integration.

\section{INTRODUCTION}

The vast majority of scientific papers on global warming are devoted to the study of climate change and natural consequences, but so far, little attention is given to the analysis of socio-economic and demographic impacts. In Russia, the most extensive research in this field is carried out in the Institute of Oceanology of the Russian Academy of Sciences. However, these studies are primarily focused on the basic problem of the oceans as a whole, including studies related to the melting of ice in the Arctic. For example, the fundamental work of V.I. Izmalkov "Trends in global climate change, its contribution to the increasing number of natural disasters, and catastrophic events, and their possible consequences" presents a detailed examination of the current trends of climate change [lzmalkov, 2012]. The paper also identifies the relationship between these trends and the number of natural disasters, such as floods, hurricanes, tsunamis, etc. This problem was further examined by G.M. Nigmetov, Y.A. Filatov, V.I. Pchelkin, and N.S. Yuzbekov in "The growth trend of catastrophic floods in the territory of the Russian Federation" [Nigmetov, Filatov, Pchelkin, Yuzbekov, 2003] and by V.A. Vladimirov, N.N. Dolgin, and V.A. Makeev in "Global problems as a source of emergency situations" [Vladimirov, Dolgin, Makeev, 2012]. M.I. Faleev (in: "Improving the protection of the population and territories, considering the experience of dealing with large-scale disasters and natural emergency situations") [Faleev, 2012] and V.A. Vladimirov (in: "Disasters and socio-economic development") address only isolated aspects of socio-economic impacts in the context of disaster prevention and protection of the population of countries and territories from climate risk [Vladimirov, 2012]. Despite the significance of these works, they are completely lacking in-depth analysis of the impact of global climate change on demographic processes, as well as of the behavior and way of life of the population living in areas of potential threats.

In recent years, the studies of specific situations in regions and countries that face maximal risks from global climate change become particularly relevant. Relevance of research with respect to Vietnam is associated with its unique geographic location. The country is literally at the epicenter of the impact of global warming. In Russia, the studies on the Vietnam situation are not yet sufficiently known. Most studies on Vietnam are done by American and Vietnamese scientists. Increased activity of American scientists is possible because of substantial governmental financial support for these studies, provided through a number of organizations and foundations: The National Aeronautics and Space Administration (NASA), National Oceanic and Atmospheric Administration (NOAA), the National Academy of Sciences (NAS), and the Central Intelligence Agency (CIA). Many of them are rather pragmatic. For example, according to the CIA press secretary, the research results will be used by the CIA to improve the policies of the national security of the USA. Many experts agree that the United States, as it was a case 60 years ago, still attempt to develop methods and techniques of managing climate and weather conditions for military 
purposes. Among the most fundamental and interesting works on Vietnam, we can list a monograph by American scientists T.W. Doyle, R.H. Dey, and T.C. Michot "Development of sea level rise scenarios for climate change assessments of the Mekong Delta" [Doyle, Dey, Michot, 2010], the work of a Vietnamese scientist Nguen Huu Ninh "Flooding of the Mekong Delta" [Nguyen, 2008], a report of the World Bank "Economic adaptation to climate change" and a report of the Ministry of Natural Resources and Environment (MONRE) "Climate change, Sea level rise scenarios for Vietnam" [World Bank, 2010]. Also, the works of American scientists P. Adams, G. Gisek, N. Tren, A. Agroel, and A. Almeyd [2011] discuss the impact of natural disasters caused by global climate change on food security in Vietnam. The main conclusion of these authors is that the problem of reduction of the acreage (primarily under rice), the destruction of part of the crop, as well as reduction in the number of species in the coastal waters of Vietnam, becomes the reality. The works also note the threat of economic slowdown and rising prices for products and services, which ultimately may lead to lower standards of living in Vietnam.

Thus, today we are dealing with a certain situation in the area of global climate change and its impact on socio-economic and demographic processes in Vietnam. On the one hand, with the support of various government agencies, international organizations, and foundations, extensive research on climate change is being conducted. However, on the other hand, obviously, the issues of assessment and forecast of the impact of global climate change on the socio-economic and demographic processes have not been sufficiently addressed. It is clear that the demographic potential of Vietnam is so high and important that global warming could have serious consequences for the country. Potential threats associated with possible relocation and resettlement of the population of the territories facing possible flooding, have not been yet examined in detail. Therefore, it is not possible to develop mechanisms, primarily at the governmental level, to minimize the possible negative consequences of forced climate migration, which may affect, in the near future, a large number of people.

\section{THE ROLE OF VIETNAM IN INTERNATIONAL MIGRATION AND THE INTEGRATION OF VIETNAMESE MIGRANTS IN HOST COUNTRIES}

Vietnam is an active participant of international migration as a donor country. In terms of the absolute number of emigrants, Vietnam ranked twenty-third country in the world in 2010; there were more than 2,2 mln people living outside the country, which comprises 2,5\% of the total country's population. The main countries of destination for Vietnamese migrants were economically developed countries such as USA, Japan, Australia, Canada, Germany, France, South Korea, United Kingdom, as well as neighboring Cambodia and Thailand. In terms of the volume of remittances received from abroad (more than 7,2 bn dollars US), Vietnam took sixteenth place in the world [Migration, 2011]. Historically, countries of Eastern Europe and the former Soviet Union have also become some of the regions of the resettlement of Vietnamese migrants. According to the Organization for Economic Cooperation and Development (OECD) and the national statistics, the number of Vietnamese people in Eastern and Central Europe (excluding the Russian Federation) is about 100 th persons. The Czech Republic is home to about 70 th, Poland - 10 th, Austria - 7 th, Hungary - 5 th, Slovakia - about 3 th, and Bulgaria - about 1 th of Vietnamese people. The exact number of Vietnamese people in Russia and the CIS is not known. According to rough estimates, in all republics of the former Soviet Union, there are at least 350-400 th persons [Ryazantsev, 2007].

Statistical data show that many Vietnamese people in Eastern Europe are naturalized, i.e., acquired the citizenship of the country of residence. This process was particularly 
intense in the last decade in Hungary, the Czech Republic, and Poland. The our study showed that the Vietnamese communities in Eastern Europe are quite complex conglomerates composed of representatives of different social classes, political trends, professional groups, and religious and ethnic communities. In socio-demographic terms, Vietnamese communities are dominated by men of young and middle age, mobile and dynamic people, prone to getting education and conducting business, and, therefore, to successful integration into the host countries. However, despite this, in Eastern Europe, not all Vietnamese people are successfully integrated into society. In 2011, scientists from the Institute of Social and Political Studies of the Russian Academy of Sciences and the Institute for European Studies of the Vietnam Academy of Social Sciences have conducted a comparative study of the processes of integration of the Vietnamese immigrants in some countries of Eastern Europe [Ryazantsev, Manshin, Nguen, 2013]. They have identified six components of the integration of the Vietnamese people into the host countries:

1) Civic integration - the possibility of naturalization and acquisition of citizenship, absence of restrictions on movement within the country, and possibility of realization of electoral rights and gaining civic identity of the host country.

2) Economic integration - access to jobs, higher incomes, access to social benefits, implementation of entrepreneurial potential, property acquisition, and property rights. Economic integration is central to the structure of the overall integration, since the socio-economic position and the level of income largely determine the overall success of integration. It is possible to assess the parameters of economic integration with a high degree of reliability, because the data exist in the official statistics.

3) Environmental integration - adaptation to climate and natural and geographical conditions. This aspect of the Vietnamese integration is extremely relevant since the migrants come from the country with fundamentally different climatic conditions than in Eastern Europe.

4) Social and psychological integration - the level of the migrants' access to education, knowledge and fluency in the primary language of the migrants' country of residence.

5) Religious integration - the ability to worship, adoption of the religion of the local population, and absence of religion-based conflicts between the migrants and the local population.

6) Cultural integration - knowledge and willingness to learn and adopt the culture and the way of life of the local population.

The integration process of migrants in the host countries is a rather multifaceted process that involves economic, cultural, social, and many other aspects. The success of the integration process depends on several factors that should be considered by migrants and a host country. Among the most important are the length of stay in the new place of residence; settlement patterns and the number of migrants; level of education and socio-economic situation of migrants; religious affiliation; perception of migrants by the local population; the legal status of migrant workers, etc. Obviously, the impact of subjective and objective factors may have dramatically opposite effects on the integration of migrants. In particular, the "openness" and "readiness" of migrants to the contacts will certainly contribute to the rapid and successful integration into the host society; in turn, isolation and concentration of residence, for sure, will give rise to a cautious attitude on the part of the surrounding population and, ultimately, will complicate the process of integration.

The study was conducted in the form of a sociological survey by experts. Eighteen interviews were taken in five Eastern European countries in migration services, employment services, and government 
agencies on the issues of integration and inter-ethnic relations in Russia, Ukraine, the Czech Republic, Poland, and Hungary. The purpose of the survey was to assess the degree of integration of the Vietnamese migrants in host societies. Experts were asked to evaluate, on a 10-point scale, each of the six components of the integration of Vietnamese people in the countries, for which they have information at the time of the survey. For each of the components of the integration, a set of parameters that help to refine expert evaluation was developed. The experts' responses were used to derive the average scores based on the six components of the integration for each of the experts' returned questionnaires and the mean values for each parameter for all experts' responses. Next, the integrated score for each of the studied countries in Eastern Europe was calculated. The results are presented in Table 1.

The study showed that most Vietnamese people have successfully integrated into the Czech Republic and Hungary. The overall score based on the expert assessment was 50 points out of 60 possible. These countries scored the highest for the civic and economic integration. It should be noted that the authorities' policy in relation to Vietnamese migrants has changed significantly in recent years in the countries of Eastern Europe. The state policy in the Czech Republic and Hungary is aimed at the need to integrate the Vietnamese people into the local society through the development of entrepreneurship and integration programs. The study shows that it has been successful. In Hungary and the Czech Republic, a significant part of Vietnamese migrants have obtained citizenship of the host country. Today, in Hungary and the Czech Republic, most Vietnamese people do not just have legal immigration status, but they became citizens of these countries. The success of economic integration is associated with a high entrepreneurial activity, penchant for doing business, professional qualifications, and access to the labor market for the Vietnamese migrants. Much less successful is the integration of the Vietnamese migrants in Russia and Ukraine, where civic, environmental, and socio-psychological components of integration remain very low. Russia scored 40 points and Ukraine - 34 points.

Unfortunately, specifically in the countries of Eastern Europe and the former Soviet Union in 1990s, because of various circumstances, many Vietnamese were deprived of legal status and were forced to exist in the informal economy. Many Vietnamese migrants were forced to change their line of business, e.g., go to the trade in the markets. As a result, in the countries of Eastern Europe and the former Soviet Union, a stereotype of Vietnamese migrants have

Table 1. Expert assessment of Vietnamese migrants' integration level in the countries of Eastern Europe

\begin{tabular}{|l|c|c|c|c|c|}
\hline \multicolumn{1}{|c|}{ Type of integaration } & Russia & Ukraine & Czech Republic & Hungary & Poland \\
\hline Civic & 6 & 4 & 10 & 10 & 7 \\
Economic & 7 & 5 & 9 & 8 & 5 \\
Environmental & 6 & 7 & 7 & 8 & 7 \\
Socio-physiological & 5 & 4 & 9 & 9 & 7 \\
Religious & 8 & 7 & 8 & 8 & 7 \\
Cultural & 8 & 7 & 7 & 7 & 6 \\
\hline Final Integration Score & $\mathbf{4 0}$ & $\mathbf{3 4}$ & $\mathbf{5 0}$ & $\mathbf{5 0}$ & $\mathbf{3 9}$ \\
\hline
\end{tabular}

Note: The study used the following scale: maximum degree of integration - 10 points, the minimum degree of integration - 0 points. 
formed: they are only traders in the markets, illegal immigrants without legal documents, etc. Ultimately, all this greatly slowed the integration of Vietnamese people in the host societies in Eastern Europe and the former Soviet Union. Meanwhile, the experience of many developed countries of the world shows that the legalization of status and naturalization of migrants though does not remove all the problems entirely, largely progressively affects the depth of the integration process.

\section{ATLAS INFORMATION SYSTEMS AS A TOOL FOR INTEGRATED DECISION- MAKING ON ORGANIZATION OF TERRITORIES}

Atlas Information Systems (AISs) are top-class electronic atlases in terms of functionality and are used as decision support systems and for development of scenarios for territories and other purposes. They have modeling functions that can be integrated into expert systems and formalized as a full-fledged multimedia design. AISs support integration of a variety of information resources, simulation, visualization, various analyzes, and even development of scenarios and options for such complex systems as "naturesociety-economy" [Tikunov, Yanvareva, 2002; Kraak, Ormeling, 2005; Ormeling, 1995, and others], which is extremely important for assessment of the socio-economic and demographic consequences of climate warming for Vietnam.

The specific feature of the structure of the AIS that is being developed by the authors is a close link between socio-political, economic (production), natural resource, and environmental blocks for the integrated assessment of the provinces of Vietnam. Together they characterize various socio- and environmental systems of different territorial ranks. All thematic subjects allow for tracking hierarchal changes - from the global (Vietnam and global climate change) to the local level, taking into account the specifics of phenomena representation at different scales. The AIS realizes the hypermedia principle, when the themes are connected through associative (semantic) relationships; for example, subjects of lower hierarchical levels not only represent specific thematic subjects on these scales, but also reflect all their detailed features. The system allows for comparison of provinces in Vietnam and other countries, where they are treated as the single information set. For these purposes, the system utilizes multivariate ranking based on complexes of comparable parameters. Along with the climatic theme, the AIS gives a fairly complete description of all components of the "nature-economy-population" system with a focus on demographic and migration processes and the nature of the changes. The blocks are supplemented with quantitative integral estimates of socio-demographic stability, sustainable economic development, resistance of the environment to human disturbance, and some other generalizing subjects. Even individual themes (and the integrated characteristics as well) not just show the actual status, but stress patterns in the development of the phenomena and display them in different ways.

The next hierarchical section of the system is a regional block, where the provinces of the Mekong Delta and Central part of Vietnam are characterized in most details. These provinces will be analyzed as part of a larger formation, i.e., the country, as well as a self-sufficient (in certain boundaries) unity capable of self-development based on the use of internal resources. The compiled maps will be used for development of strategies and priority management decision making for each province. The provinces were classified and typical representatives of various groups (industrial, agricultural, etc.) have been identified; these groups require specific measures for protection of the population. The authors intend to create several regional components of the system, which would represent different types of the areas in the country. The block-system principle will be utilized to separate logical blocks that can be modified, supplemented, or 
expanded without changing the structure of the entire system.

The theme related to the demographic and migration aspects requires a dynamic assessment of almost all the thematic subjects, which is implemented in accordance with the principles of evolutionary dynamics in the AISs. These are the characteristics of the main phenomena for the baseline time-intervals or years. For a number of subjects in retrospective analysis, the authors have developed several thematic animations, such as flooding scenarios at different rates of climate change.

The most important application of the system is the simulation of scenarios for the development of the country and its provinces. In this case, the multi-variant principle is realized, which offers the end user a number of solutions, such as optimistic, pessimistic, etc., scenarios. With these scenarios becoming increasingly more complex, there arises an urgent need for the intellectualization of the system, when the expert facilitates obtaining feasible results in conditions of high complexity and not quite clearly defined tasks.

The AIS that is being developed can offer a meaningful simulation of complex phenomena. This modeling is based on the integrated system approach to socioenvironmental systems modeling. Thus, a system user can model certain structures, whose management includes different options associated with extreme change and assessment of necessary expenditures in order to prevent critical developments of events. Simulation tools that will be developed will primarily target various demographic and migration scenarios. The final stage of the project related to the intellectualization of the whole system, will form a full-scale decision support system. Finally, it should be noted that the system is based on the multi-media principle (hypermedia), which facilitates the decisionmaking process.

\section{ASSESSMENT OF THE SOCIO-ECONOMIC AND DEMOGRAPHIC CONSEQUENCES OF GLOBAL WARMING FOR VIETNAM}

According to the report by the World Bank, Vietnam is among the five countries most vulnerable to water level rise in the oceans due to global warming. The most densely populated and economically important, for Vietnam, areas are in the zone of potential flooding. In Vietnam, the average increase in temperature will lead to unprecedented hitherto storms, tsunamis, and, as a consequence, to flooding. According to the forecasts of the World Bank, by 2040, increase in water level could reach $30 \mathrm{~cm}$. The simulation of this forecast showed that the flood zone will affect several provinces in Vietnam: An Giang, Kien Giang, Hau Giang, Dong Thap, Lon An, Tien Giang, Vinh Long, and Can Tho.

Warming poses a particular hazard to the region of the Mekong Delta. The Mekong Delta is one of the most densely populated areas of Vietnam with about $20 \mathrm{mln}$ people. Our preliminary estimates indicate that about $6 \mathrm{mln}$ people may be in the area of flooding in the Mekong Delta (Table 2). Note that these demographic estimates are preliminary.

Being the largest granary of the country, this area plays a vital role in the food security strategy in Vietnam and the world. Here, rice fields cover about 3,8 $\mathrm{mln}$ hectares with a yield of more than $20 \mathrm{mln}$ tons per year. In general, these areas account for more than half of the production of all crops, particularly aquaculture (primarily rice), whose share exceeds 75\%. According to some scientists, the majority of disasters occurring in the delta of the Mekong River were caused by the impact of climate change, particularly sea-level rise. In one of his scientific papers, Dr. Huu Ninh Nguyen (Department of Environment and Natural Resources, University of (an Tho) states: 
Table 2. The Mekong Deta provinces most vulnerable to sea level rise flooding

\begin{tabular}{|l|c|c|c|c|c|}
\hline \multirow{2}{*}{ Provinces } & \multirow{2}{*}{$\begin{array}{c}\text { \% flooded } \\
\text { area*** }\end{array}$} & \multicolumn{2}{|c|}{ Population, th people, 2012 r. } & \multicolumn{2}{|c|}{ Territory, sq km } \\
\cline { 3 - 6 } & 24.7 & Total** & In the flooded area & Total** & In the flooded area \\
\hline Can Tho & 1214.1 & 299.9 & 1409 & 348 \\
Ben Tre & 51 & 1258.5 & 641.8 & 2358 & 1203 \\
Long An & 49.4 & 1458.2 & 720.4 & 4492 & 2219 \\
An Giang & $\ldots$ & 2153.7 & $\ldots$ & 3537 & $\ldots$ \\
Dong Thap & $\ldots$ & 1676.3 & $\ldots$ & 3377 & $\ldots$ \\
Vinh Long & $\ldots$ & 1033.6 & $\ldots$ & 1505 & $\ldots$ \\
Bac Lieu & 39.9 & 873.4 & 348.5 & 2469 & 985 \\
Soc Trang & 43.7 & 1301.9 & 568.9 & 3312 & 1447 \\
HCM City* & 43 & 7681.7 & 3303.1 & 2096 & 901 \\
\hline Total & - & $\mathbf{1 8 6 5 1 . 4}$ & $\mathbf{5 8 8 2 . 6}$ & $\mathbf{2 4 5 5 5}$ & $\mathbf{7 1 0 3}$ \\
\hline
\end{tabular}

Notes: * Officially, part of the Southestern provinces of Vietnam.

** Source: The General Statistics Office of Vietnam http://www.gso.gov.vn/

*** Source: Can Tho University. The Climate Change Research Institute

"The area of the delta of the Mekong River is experiencing severe consequences of global climate change. With each passing day, the area of saline, dry, and contaminated soil with heavy metal salts is getting increasingly greater. Throughout the Mekong Delta, there are 2,1 $\mathrm{mln}$ hectares of saline soils and $1.6 \mathrm{mln}$ hectares of dry soils and soils contaminated with salts".1

A sharp rise in the river level has led to the fact that about 70 th hectares of orchards and hundreds of kilometers of rural roads were heavily flooded. A serious concern is that the flooding occurs not only in the rainy season, but in the dry season as well. Residents of the area of the Mekong River Delta still cannot forget the strong tides, accompanied by high rainfall in December 2009, resulting in flooding of hundreds of thousands of hectares of fruit trees and crops. Flooding of fertile lands in the Mekong River Delta will lead to increased soil salinity, which will make them unsuitable for rice cultivation. This fact is further compounded by increasingly growing role of Vietnam as an important strategic exporter of rice in Southeast Asia. Another problem in terms of food security in Vietnam and the region

\footnotetext{
${ }_{1}^{1}$ Disasters have been exposed, VietNamNet Online Newspaper (http://english.vietnamnet.vn/fms/special-reports/96662/ disasters-have-been-exposed.html).
}

as a whole will be the flooding of large marine areas designated for fishing. Rising sea levels and changes in alkaline and acid balance may lead to disappearance of coral reefs and, as a consequence, many types of fish and shellfish. The Vietnam water area accounts for up to $16 \%$ of the total catch of the countries of Southeast Asia. Rice and seafood are the basis of the diet of the inhabitants of these countries.

In addition to the above-mentioned threats associated with global warming, we can identify strengthening typhoons and storms, as well as the reduction of the Vietnam territory itself. The result of increasing number of floods in Vietnam may be the loss of $6 \%$ of the territory. According to the forecast, if the sea level rise averages 78-95 cm, and in some coastal areas of the country - up to $105 \mathrm{~cm}$, seven coastal provinces of Vietnam may be flooded. About 40\% of the Mekong Delta will be flooded and more than 10\% of the Red River Delta and Quang Ninh.

There is a significant discrepancy between the number of the population of Vietnam and the size of territories suitable for human habitation. Over the past five years, some areas in Vietnam lost entire streets in the villages because of river flooding. Thus, in 2010, in the county Namcan, province 
Table 3. Provinces of the Central Vietnam affected by typhoons and storms

\begin{tabular}{|c|c|c|}
\hline \multirow{2}{*}{ Provinces } & \multicolumn{2}{|c|}{ Key parameters } \\
\hline & Population th people (2012) & Territory, sq km \\
\hline Binh Dinh & 1501.8 & 6050 \\
\hline Da Nang & 973.8 & 1285 \\
\hline Phu Yen & 877.2 & 5061 \\
\hline Quang Binh & 857.2 & 8065 \\
\hline Quang Nam & 1450.1 & 10438 \\
\hline Quang Ngai & 1227.9 & 5153 \\
\hline Quang Tri & 608.1 & 4740 \\
\hline Total & 7460.1 & 40792 \\
\hline
\end{tabular}

** Source: The General Statistics Office of Vietnam (http://www.gso.gov.vn/)

Camau, a 20 m river bank collapsed and took a few home and people's lives. According to the local residents, such incidents began to occur only in the last 10 years. In one village, situated on the bank of the river, there was a fracture of the earth. The only way used by the government of Vietnam and by the people to mitigate these events is the construction of new dams, as well as strengthening the existing ones. However, with each passing year, more and more people realize that this mechanism has a diminishing positive effect. A potentially stronger tropical storm is able to cause significant damage to dams, which must be again built and strengthened.

To solve this problem, back in 2008, the Vietnamese authorities adopted the governmental target program to respond to climate change. The Ministry of Natural Resources and Environment was commissioned to create a scenario of climate change and sea level rise in Vietnam. However, it is obvious that under the circumstances, the government of Vietnam and the country's people cannot cope with the impending threat. The problem requires an immediate response at the international level, as a threat cannot be localized within the borders of Vietnam.

Obviously, flooding may require relocation of the population in the country and, possibly, beyond its borders. If the relocation of people does not happen gradually, a reduction in the Vietnam territory with high population density, the specifics of the settlement, and reproduction trends can cause significant flow of forced migrants - environmental refugees. The territory of Vietnam may not be sufficient to absorb the entire flow of immigrants and, as a result, they will be moving out of the country. However, if the resettlement program starts now in the form of organized labor migration, it is possible to anticipate and mitigate the negative scenario. Besides, organized labor emigration could even bring Vietnam socioeconomic benefits. Actually now, Vietnam is already seeing these socio-economic effects of labor migration. With the development of programs of organized labor migration from the territories at risk from flooding, the country will "kill two birds with one stone", i.e., it will avoid forced environmental migration.

\section{MIGRATION POTENTIAL OF VIETNAM}

The study has approximately estimated the migration potential of Vietnam, including the Russia-oriented. The population of Vietnam, between 1980 and 2009, increased by nearly $33 \mathrm{mln}$ people and reached 86 $\mathrm{mln}$. During the reporting period, there were different rates of population growth, but the biggest was registered in 2005: $2 \mathrm{mln}$ people. The age structure of the population changed in recent years 
towards reduction of the proportion of children and increase in the share of the working-age and the retirement-age people. The working-age population in Vietnam is about $58 \mathrm{mln}$ people, or $67.9 \%$ of the population. Since it is difficult to obtain official statistics on population by provinces in Vietnam, for our calculations, we relied on the numbers presented above and calculated the working-age population in the studied provinces.

Assessment of migration potential was made based on the data of the survey conducted in 2009 and some very limited statistical sources. First, we calculated the number of people who had experience of working and studying abroad. It is about $12,5 \%$ of the working population. Then, $35,7 \%$ of respondents of our survey said that they wanted to work abroad in different countries. Russia, unfortunately, does not occupy a significant place in this respect. Only 3,3\% of our respondents wished to work in Russia. Thus, we performed the calculations, whose results are presented in Table 4.
The population of Vietnam has a young demographic profile, which is a good base for the export of labor and workers in training. Our calculations show that the country has a significant migration potential: at the time of the study, it was about 2,6 mln people. In the studied provinces, the migration potential was about 720 th people, including about 200 th in Vietnam's capital - the city of Hanoi. Specifically that many people could become labor and education migrants. However, the implementation of migration systems depends on a number of factors, both in Vietnam and receiving countries. The Vietnamese economy is now actively developing and is absorbing a significant part of the workforce, while countries that attract migrant workers from Vietnam have different economic and political priorities, which may change. Much depends on the migration policy of the host country, the activity of state bodies, companies, and private employment agencies.

Calculations show that in Vietnam, migration potential focused specifically on Russia may be 85,3 th people. In the studied provinces,

Table 4. Assessment of migration potential of the provinces in Vietnam

\begin{tabular}{|c|c|c|c|c|c|}
\hline City, province & $\begin{array}{c}\text { Total popula- } \\
\text { tion, } \\
\text { th people }\end{array}$ & $\begin{array}{c}\text { Working-age } \\
\text { population }\end{array}$ & $\begin{array}{l}\text { Population } \\
\text { with experi- } \\
\text { ence working } \\
\text { abroad }\end{array}$ & $\begin{array}{l}\text { Migration po- } \\
\text { tential } \\
\text { for work and } \\
\text { study abroad, } \\
\text { th people }\end{array}$ & $\begin{array}{c}\text { Including } \\
\text { migration po- } \\
\text { tential } \\
\text { for Russia, } \\
\text { th people }\end{array}$ \\
\hline Vietnam & $86,024.6$ & $57,917.0$ & $7,239.6$ & $2,584.5$ & 85.3 \\
\hline Hanoi & $6,472.2$ & 4,394.6 & 549.3 & 196.1 & 6.4 \\
\hline Bac Ninh & $1,026.7$ & 697.1 & 87.1 & 31.1 & 1.0 \\
\hline Vinh Phuc & $1,003.0$ & 681.0 & 85.1 & 30.4 & 1.0 \\
\hline Bình Thuan & $1,784.0$ & $1,211.3$ & 151.4 & 54.1 & 1.8 \\
\hline Nam Định & 1.826 .3 & $1,240.1$ & 155.0 & 55.3 & 1.8 \\
\hline Hai Phong & $1,841.7$ & $1,250.5$ & 156.3 & 55.8 & 1.8 \\
\hline Hai Duong & $1,706.8$ & $1,158.9$ & 144.9 & 51.7 & 1.7 \\
\hline Bac Giang & 1.560 .2 & $1,059.4$ & 132.4 & 47.3 & 1.6 \\
\hline Hoa Binh & 789.0 & 535.7 & 67.0 & 23.9 & 0.8 \\
\hline Thanh Hoa & $3,405.0$ & 2,312.0 & 289.0 & 103.2 & 3.4 \\
\hline Ha Tay & $1,230.3$ & 835.4 & 104.4 & 37.3 & 1.2 \\
\hline $\begin{array}{l}\text { Overall in the } \\
\text { studied prov- } \\
\text { inces }\end{array}$ & $22,645.2$ & $16,211.5$ & $2,026.4$ & 723.4 & 23.9 \\
\hline
\end{tabular}


the potential was 23,9 th people, including 6,4 th people in Hanoi. We can say that Russia has exhausted its capacity for receiving Vietnamese migrants at the current level of its migration policy. We should recall that in 2008, Russia had 99,2 th of Vietnamese labor and education migrants. It means that Russia cannot take any more Vietnamese migrants than it has now with the modern approach to the management of migration from Vietnam, the labor market, and the education system. Russia needs a conceptual change in the migration policy towards Vietnam and transition to the active form of the migration to enhance the migration potential focused specifically on Russia.

\section{HISTORY AND PROSPECTS OF ATTRACTING VIETNAMESE MIGRANTS IN RUSSIA}

When, in the 1980s, the USSR experienced labor shortages, it signed an agreement with Vietnam on the invitation of Vietnamese workers. The Intergovernmental Agreement signed on April 2, 1981, marked the beginning of large flows of labor migrants from Vietnam to the USSR. Under this Agreement, the country accepted over 103 th people at 370 industrial enterprises of the seven Soviet republics, especially, the Russian Federation (83\%). At some individual enterprises, the share of Vietnamese workers reached 10$15 \%$ of the total number of employees. This program was so successful that the number of ministries and departments receiving Vietnamese workers increased from 4 in the beginning of the program to 30 over some time. Vocational training was conducted for 70 occupations. About 50\% of the citizens of Vietnam worked at enterprises of light and textile industry, 15\% - in engineering, $16 \%$ - in construction, and the rest - in the coal, chemical, and other industries. The sectoral structure of employment of Vietnamese workers was quite stable throughout the period of involvement of Vietnamese migrants in the USSR. The main centers of attraction of the Vietnamese labor force were in the Central and Volga regions and Western Siberia.
Since 1991, following the collapse of the USSR, the Vietnamese side has suspended sending new migrant groups. The existing employment contracts were 4 years for women and 6 for men and could be extended by no more than one term, which caused rotation of personnel. Upon expiry of work or study, the migrants returned to Vietnam; there was practically no intermarriage. Nevertheless, in 1991, the USSR had 150 th of Vietnamese migrants. With the collapse of the USSR, they have lost their jobs and livelihoods. In contrast to the former East Germany, Russia did not even provide for their return tickets and did not help with the departure, although many have been denied re-registration, which deprived them of the opportunity to legally reside in Russia. The Vietnamese workers were forced to trade the markets. In early 1996, the contracts of the last group of Vietnamese migrants expired and, officially, no Vietnamese workers remained in Russia (as a rule, they were dismissed). The governments of both countries did not want to assist migrants to return home. Russia and Vietnam have not fulfilled the obligations to pay employees return fairs (most companies did not have the money to buy tickets to Vietnam and no mechanism for punishing the managers of debtor companies were in place). The circumstances forced the Vietnamese migrants to adapt to the new socio-economic conditions of existence, to survive on one's own risk. Overall, 81 th people went through the formal process of repatriation, however, some illegally remained in Russia. In addition, 17.6 th Vietnamese workers entered Russia outside the agreement, 278 died, 81 people were jailed, and 93 were married to the locals and received Russian citizenship. Based on these data, we can conclude that if about 5 th people avoided returning home, the total number of "defectors" amounted to 10-15 th persons. Although the agreement of 1981 has been actually executed, it formally remained valid until recently. In the course of the structural reforms in Russia, the earlier system of remuneration for labor has been disrupted. Russia became a debtor to Vietnam, and the debt continued to 
grow. Initial payments by Russia and, thus, income to Vietnam, included $60 \%$ of the amounts for social insurance for workers and partial reimbursement of expenses for their selection. In addition, Vietnamese citizens were transferring $10 \%$ of their salary to their homeland.

The second Intergovernmental Agreement on the principles and directions of reception of Vietnamese citizens for work in Russia, signed on September 29, 1992, essentially did not work because of the beginning of the structural changes in the Russian economy and the reorganization of departments and ministries. 1,3 th ofVietnamese citizens moved to Russia and, since 1994, the government of Vietnam has ceased to supply workers to Russia at all. Vietnamese workers had to sign employment contracts with their employers, indicating the scope of work based on the authorization of the Ministry of Federal Affairs and Nationalities (currently, this agency does not exist in Russia). However, due to changes in the conditions of the economy, many businesses, where Vietnamese citizens came to work, just closed. Many migrant workers have registered with the aim to obtain temporary residence permits and became legal residents. Since there was no work in industrial enterprises, many Vietnamese were engaged in trade, shuttle business, and entrepreneurship.

The Third Agreement on temporary employment of Vietnamese citizens in Russia was signed on August 18, 2003. Its main drawback was that it did not specify the quantitative parameters of immigration. This agreement recognized the legitimacy of stay of citizens of Vietnam, arrived under the Agreement of April 2, 1981, subject to their registration at the Embassy of Vietnam and a work permit in Russia. An important part of the Agreement is the clause of independent finding jobs by Vietnamese citizens in Russia (Article 2 of the Protocol of the Agreement).

Currently, in Russia, the issue of the selection of priority countries to attract migrant workers is being widely discussed. Given the long historical experience, economic and geopolitical impacts, as well as the substantial adaptive capacity of the Vietnamese people, Vietnam could become one of the countries, from which Russia could attract organized labor migrants midterm.

In this regard, the mechanism of regulation of migration between Russia and Vietnam needs to be improved. Some positive steps in this direction have been made recently. With the active participation of the Federal Migration Service, Russia has prepared a number of documents, allowing better management of labor migration. In October 2008, during the visit of the President of Vietnam to Russia, three agreements on migration between the two countries were signed.

The first agreement is on temporary employment of Vietnamese citizens in Russia and Russian citizens in Vietnam. This agreement, for the first time ever, clearly defines the issues of attracting migrant workers and guaranteeing them rights and freedoms. In addition, the agreement was supplemented with a protocol that regulates the status of Vietnamese migrants who remained in Russia after the collapse of the USSR and, for a long time, had no official status. The protocol identifies three conditions under which citizens of Vietnam, arrived under the Agreement of April 2, 1981, to work in the USSR, can continue their career in Russia. They need to get a permit to work in Russia (and the protocol establishes a simplified procedure for obtaining this permit), to embark on migration registration in accordance with the laws of Russia, and to register with the embassy or consulate of Vietnam. One must also have a valid national passport and meet these conditions within six months after the entry into force of this document. In our view, the agreement will finally settle the status of many Vietnamese workers, bring them out of the informal economy, reduce the opportunity for corruption, and will allow people to feel more secure in the territory of Russia. 
The second document is an agreement on cooperation in the fight against illegal migration. It expresses the intention of Russia and Vietnam to implement measures to prevent illegal migration. It is known that part of the migration from Vietnam is illegal. In this regard, it is important that Russia was successful to persuade the Vietnamese authorities to take responsibility for coordinating the activities in the field of not only the fight against illegal immigrants, but also to take measures to prevent such flows.

Finally, the third document is the readmission agreement. The term "readmission" refers to the transfer by the competent authorities of one state to another workers who are in the territory of another state in violation of the law. This document will resolve the issue with the transit of illegal migrants who are trying to get through Russia to Western Europe. This area of migration policy can be called "breakthrough" for the Russian-Vietnamese relations in the area of migration.

The specific feature of migration to Russia from Vietnam is the visa regime. Beginning in 2009, Vietnam unilaterally stopped requiring visas for Russian citizens who stay for no longer than 15 days. This has a positive impact on increasing the flow of Russian tourists to Vietnam, making it easier to stay in Vietnam for business and scientific purposes. On the contrary, the Russian migration policy regards Vietnam as a "migration dangerous country". This is reflected in the passport and visa procedures. Vietnamese nationals are required to obtain a Russian visa based on the invitation made through the Ministry of Internal Affairs by the host organization. When it comes to migrant workers, this is done by potential employers under the quotas for foreign labor. When it comes to education migrants, it is done through colleges. Visas are granted based on these invitations. Our survey has identified that about $46 \%$ of Vietnamese migrants were in Russia through work visas and 33\% on education visas. A proportion of visitor visas is very significant and reaches $14 \%$. We should admit that the Russian visa policy towards Vietnam is asymmetrical; it has nontransparent procedures for issuing visas and highly bureaucratized; and it takes a long time to obtain a visa for scientists from Vietnam. The Russian authorities should reconsider their visa policy towards Vietnam. The situation has changed dramatically and, now, the stiff visa policy seriously hampers the development of relations between the two countries.

\section{CONCLUSIONS}

There are at least three reasons to efficiently improve the mechanisms regulating the migration between Russia and Vietnam.

First, the involvement of Vietnamese people in Russia meets Russia's geopolitical interests; in fact, many times at the highest level (including the President of the Russian Federation) it was stated that Vietnam is Russia's strategic partner in Southeast Asia. Unfortunately, the two countries have asymmetric visa relations: Russian people can stay in Vietnam 15 days without visas and visas are required for Vietnamese people to visit Russia. In 2009, Vietnam unilaterally abolished visas for Russian citizens who come to Vietnam for a short time. This has a positive impact on increasing the flow of Russian tourists to Vietnam, making it easier to stay in Vietnam for business and academics. This step of the Vietnamese authorities can be regarded as definitely positive aspect of the Russian-Vietnamese relations. The migration policy of Russia should be more liberal with regard to Vietnamese people, which would enhance the prestige of Russia as a state in the eyes of Vietnamese people and promote the growth of migration attractiveness of the country.

Second, the liberal migration policy towards Vietnam must meet the mission of Russia as a great power and self-sufficient country. The Russian Federation has declared that it is emerging as a donor of international development. Russia can move to concrete steps and invest in the development of 
organized labor migration from the regions of Vietnam at risk of flooding as a result of global warming. And if the USSR and Russia were receiving migrant workers from the northern provinces of Vietnam, the geography now can broaden and migrant workers from the southern provinces of Vietnam can be attracted too. Of course, this will require monetary inputs for studying Russian language and opening training centers in Vietnam. However, precisely the organized labor migration should be welcomed. This approach to labor migration would have mutual economic benefits and strengthen the relations between the two countries. Most importantly, this would enhance the credibility of Russia as a country that promotes international development.

Third, the migration policy focused on Vietnam corresponds to the pragmatic interests of Russia. Vietnamese migration is much more efficient than the migration of many neighboring countries because of the presence of the Vietnamese investment and entrepreneurs already in Russia, positive practices, historical experience, high level of organization of Vietnamese migrant workers, and preparedness Vietnam to regulate flows in an organized way.

The Vietnamese migration for some sectors of the Russian economy is needed; it is much more efficient and more profitable from the economic and political point of view, than, for example, the Chinese migration. At the level of the migration policy, individual quotas for Vietnam by industry and region of Russia should be allocated, considering the areas where Vietnamese workers'labor is needed and economically justified. Given the long distance between Vietnam and Russia and more stable migration inspirations of Vietnamese people, long-term contracts should be considered with issuing work visas for longer periods, for example, for 3 to 4 years (currently, the maximum period is 1 year). A network of companies and organizations that can train migrants should be developed in Vietnam, so the migrants can receive certain skills prior to their arrival in Russia. It is feasible to organize learning centers for the Russian language basics and culture in Vietnam, which would prepare migrants for life in Russia and generate streams of education migrants. Work towards increasing efforts for recruitment of education migrants should be enhanced. Both countries need to restore the lost scientific and education ties; it is necessary to open courses in Russian language, distribute literature, information on the Russian universities, and allocate sufficient amount of scholarships and grants for students from Vietnam.

Only such drastic measures would enable increasing migration potential from Vietnam to Russia. Otherwise, Russia would be content with the number of work and education migrants, which it has now, with some very insignificant variations within the statistical error.

\section{ACKNOWLEDGEMENTS}

The study was conducted with the support of the Russian Foundation for Basic Research (№ 15-55-54006) and Russian Humanitarian Scientific Fund (№ 13-22-09001).

\section{REFERENCES}

1. BRICS Joint Statistical Publication 2011 (http://ru.worldstat.info/Asia/Viet_namLClimate change, Sea level rise scenarios for Vietnam, Ministry of Natural Resources and Environment (MONRE), Viet Nam, 2009 (http://preventionweb.net/go/11348) Disasters have been exposed, Viet Nam Net Online Newspaper (http://english.vietnamnet.vn/fms/ special-reports/96662/disasters-have-been-exposed.html)

2. Doyle T.W., Day R.H. and Michot T.C., Development of sea level rise scenarios for climate change assessments of the Mekong Delta, Vietnam, US Geological Survey, Open-File, Report 2010-1165, 2010. 
3. Faleev, M.I. Improved protection of population and territories with the experience of dealing with large-scale catastrophes and natural disasters // Civil Protection Strategy: Issues and research. - 2012, № 1 (http://cyberleninka.ru/article/n/sovershenstvovaniezaschity-naseleniya-i-territoriy-s-uchetom-opyta-preodoleniya-krupnomasshtabnyhkatastrof-i-stihiynyh-bedstviy) (Viewed: 29.06.2014).

4. Izmalkov, V.I. Trends in global climate change and its effect on increasing the number of natural disasters, catastrophes, and their possible consequences // Civil Protection Strategy: Issues and research. - 2012, № 1 (http://cyberleninka.ru/article/n/tendentsiiglobalnogo-izmeneniya-klimata-zemli-i-ego-vliyanie-na-uvelichenie-kolichestva-stihiynyh-bedstviy-katastrof-i-ih-vozmozhnye) (Date of application: 29.06.2014).

5. Kraak M. J., Ormeling, F. Cartography: Visualization of geospatial data. Translated from English. V.S.Tikunov (Ed.). - Moscow, Scientific World, 2005, 325 p.

6. Kuznetsov, N.G., Ryazantsev, S.V. The ways to use migration potential of Vietnam in Russian (article, part 1) // Asia and Africa today. - № 6, 2011 - pp. 36-42.

7. Kuznetsov, N.G., Ryazantsev, S.V. The ways to use migration potential of Vietnam in Russian (article, part 1) // Asia and Africa today. - № 6, 2011 - pp. 33-35.

8. Labor and Employment in Russia 2011: Statistical Yearbook. - M.: Rosstat, 2011.

9. Migration and Remittances Factbook 2011. The World Bank. 2011.

10. Nguyen, Huu Ninh, Flooding in Mekong River Delta, Viet Nam, Human Development Report 2007-2008 (http://www.tiempocyberclimate.org/annex/cered/HDR07.pdf)

11. Nigmetov, G.M., Filatov, Y.A., Pchelkin, V.I., Yuzbekov, N.S. The growth trend of catastrophic floods on the territory of the Russian Federation // Technologies of civil security. - 2003, № 1-2 (http://cyberleninka.ru/article/n/tendentsiya-rosta-katastroficheskih-navodneniy-na-territorii-rossiyskoy-federatsii) (Viewed: 29.06.2014).

12. Ormeling F. Atlas Information Systems - 17th Int. Cartogr. Conf. and 10th Gen. Assembly ICA. Barcelona, Sept. 3rd - 9th, 1995. Proceedings, vol. 2, Barcelona, 1995, pp. 2127-2133.

13. Ryazantsev, S.V. Labor migration in the CIS and Baltic countries: trends, implications, and regulation. M. Formula Prava, 2007.

14. Ryazantsev, S.V. Trafficking for labor exploitation and illegal labor migration in the Russian Federation: the forms, trends, and resistance: A report in the framework of the project "ADSTRINGO". - Stockholm, 2013.

15. Ryazantsev, S.V., Manshin, R.V., Nguen, Canh Toan. Comparative analysis of the Vietnamese and Chinese migration to Russia // Immigration Law. 2013, № 1.

16. Statistical Yearbook for Asia and the Pacific 2011, United Nations Publication, № E-11-IIF-1, 2011.

17. The ways to organize and protect migrant workers in agriculture and related industries. Geneva: International Union of Food, Agricultural, Agriculture, Hotel, Restaurant, Cater- 
ing and Allied Workers. Geneva 2008 (www.fpkk.ru/text/migrantsbook.pdf) (Viewed: 29.06.2014).

18. Tikunov, V.S. Yanvareva, L.F. Atlas information systems - the basis for the adoption of integrated solutions for the organization of the territory. - In: Digital Earth, Electronic Russia, Electronic Moscow: Methodology and Technology, Moscow, IPI RAN, 2002, pp. 46-52.

19. Vietnam - Economics of adaptation to climate change, Washington DC, World Bank, 2010 (http://documents.worldbank.org/curated/en/2010/01/16441103/vietnam - economics - adaptation-climate-change)

20. Vladimirov, V.A. Disasters and socio-economic development strategy // Civil Protection: Issues and research. - 2012, № 1 (http://cyberleninka.ru/article/n/katastrofy-i-sotsialnoekonomicheskoe-razvitie) (Viewed: 29.06.2014).

21. Vladimirov, V.A., Dolgin, N.N., Makeev, V.A. Global issues as a source of emergency // Civil Protection Strategy: Issues and research. - 2012, № 1 (http://cyberleninka.ru/article/n/ globalnye-problemy-kak-istochnik-chrezvychaynyh-situatsiy) (Viewed: 29.06.2014).

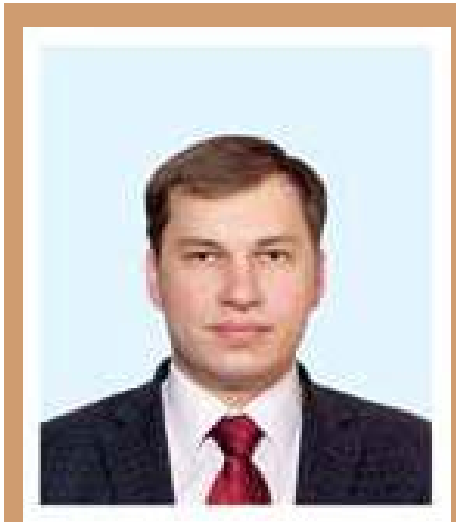

Artem S. Lukyanets is Senior Research Associate at the Institute of Socio-Political Research of the Russian Academy of Sciences. In 2006, he graduated from Stavropol State University in global economics. In 2009, he defended his Ph.D. dissertation "Immigration in the USA: trends and approaches to regulation". The same year, Dr. Lukyanets became a recipient of the award by the President of the Russian Federation for talented youth. He leads a number of research projects supported by the Russian Foundation for Fundamental Research and the Russian Humanitarian Scientific Foundation. He participates in international scientific-practical conferences, symposiums, and roundtable discussions. He published over 40 works in national and foreign scientific journals.

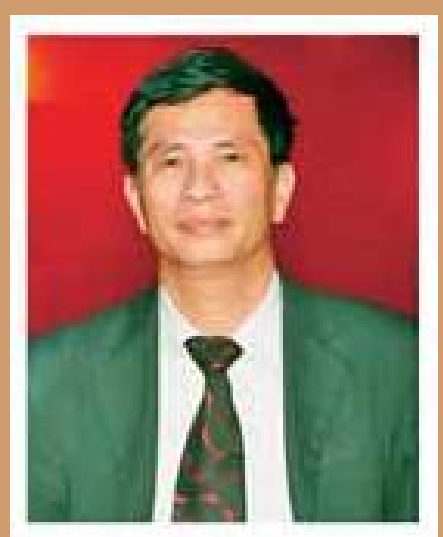

Nguen Canh Toan is Doctor of Sciences (Economics), Leading Researcher at the Institute for European Studies, the Vietnam Academy of Social Science (VASS). His research is focused on international integration, labor market in Vietnam, Vietnamese communities abroad, migration policy, and economic relations between Russia and Vietnam. Dr. Nguen teaches courses on "International relations and the global economy" and "International migration" at universities of Vietnam and Russia. He participated in a number of conferences in Vietnam, Russia, Korea, and other countries. Dr. Nguen is the author of over 90 scientific works, including 5 monographs. Currently, he leads 3 research projects funded by the Russian Humanitarian Scientific Foundation and VASS on Vietnamese migration, Vietnamese communities abroad, and demographic and migration consequences of global warming in Vietnam. 


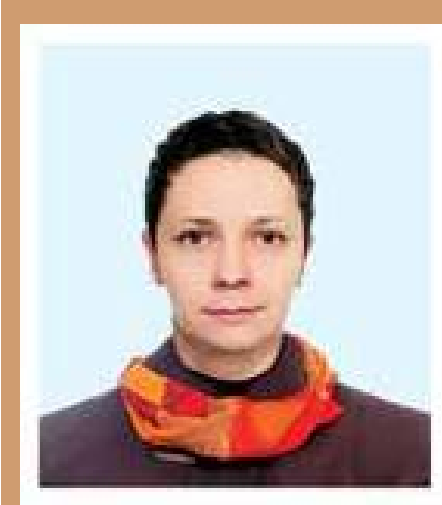

Elena E. Pismennaya is Doctor of Sciences (Sociology), Professor at the Department of Theoretical Sociology, Financial Academy under the Government of Russian Federation, Leading Researcher of the Center for Social Demography and Economic Sociology, Russian Academy of Sciences. Her research interests are in the area of sociology of migration, education migration, and adaptation of foreign migrants in Russia. She leads several research projects funded by the Russian Humanitarian Scientific Foundation, the Russian Foundation for Basic Research, and the Grant of the President of the Russian Federation for young D.Scs. She is the author of more than 100 scientific works on the issues of education and labor migration, including monographs, scientific papers, and presentations at international scientific conferences on the issues of migration and adaptation of migrants in the Russian Federation.

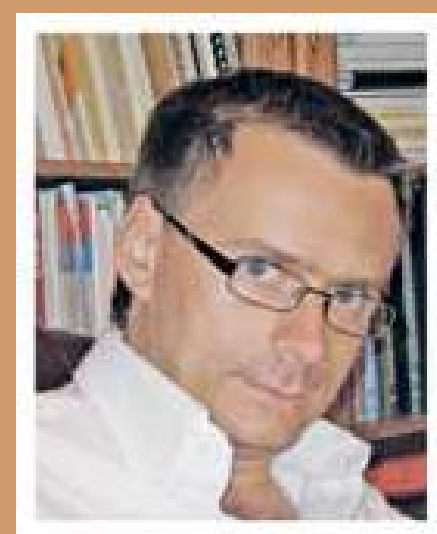

Sergey V. Ryazantsev, Corresponding member of the Russian Academy of Sciences (Sociology and Demography), Doctor of Sciences (Economics, Demography), Professor. He is head of the Center of Social Demography and Economic Sociology of the Institute of Socio-Political Research, the Russian Academy of Sciences. The area of his scientific interests is social-economic and demographic aspects of migratory processes in Russia and foreign countries. He is the author more than 400 scientific publications, including monographs "Russians Abroad" (2014), "Modeling of labor migration in Central Asia" (2013),"The Chinese migration to Russia: consequences, trends, and approaches to regulation" (2010), "The Atlas of demographic development of Russia" (2009). He is Member of the Scientific Council of Federal Migration Service of the RF, Ministry of Labor of the RF, and RF State Duma Labor and Social Policy Committee. Dr. Ryazantsev leads and participates in a number of research projects funded by the RF Ministry of Health and Social development, the RF Ministry of Education and Science, ILO, IOM, UNFPA, UN ESCAP, Council of the Baltic See States, and other organizations. He was a Visiting Professor at a number of universities, including, the University of California, Davis (USA, as a Fulbright Professor), Hokkaido University (Japan), University of State of Rio-de-Janeiro (Brazil), Hitotsubashi University (Japan), and European University Institute (Italy). 


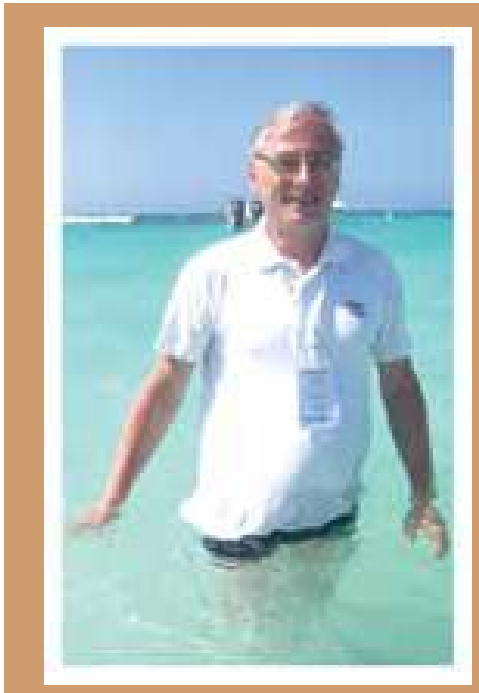

Vladimir S. Tikunov is Professor, Head of the Integrated Mapping Laboratory, MSU Faculty of Geography, and Director of the Center of the World Data System for Geography. He has led a number of Russian and international projects. His work has been used in many thematic maps and atlases: National Atlas of Russia (editor-in-chief of Vol. 3), Environmental Atlas of Russia, Atlas of Socio-Economic Development of Russia, Atlas of the Khanty-Mansi Autonomous District - Yugra, etc. He is a recipient of the D.N. Anuchin Award for his work in mathematical cartographic modeling. He is also a recipient of the Award in Science and Technology of the Russian Federation Government for the development of environmental and natural-resources atlases of Russia. He was Vice-President and, currently, is Chairman of the commission of the International Cartographic Association and a member of the Commission on Geographic Information Science of the International Geographical Union. He has been a member of the editorial boards of nine Russian and international journals. He lectured at a number of national and international universities. He has been organizing, beginning in 1994, annual international conferences InterCarto-InterGIS "Sustainable Development of Territories: GIS Theory and Practical Experience" that take place both in Russia and abroad. He published over 500 scientific works, including 14 monographs, texbooks, and manuals in 28 countries of the world and in 14 languages.

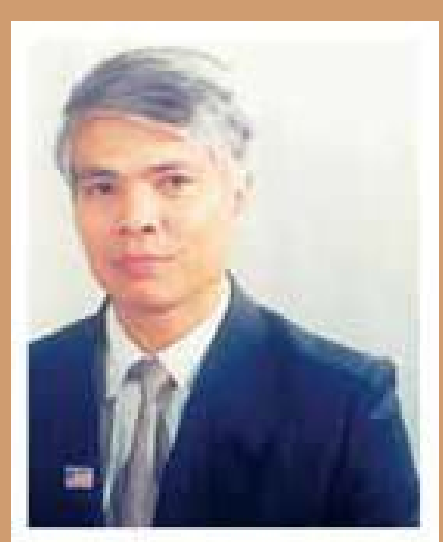

Pham Hoang Hai is Professor, Doctor of Sciences (Geography), former Deputy Director of the Department of Environmental Geography, Institute of Geography, the Vietnam Academy of Science and Technology, and Director of the Vietnam Environment and Sustainable Development Institute. At present, he is VicePresident of the Association of Vietnamese Geographers. He received the Hồ Chí Minh Prize for his work (in co-authorship) on three maps of the National Atlas of Vietnam (Chemical-Landscape Map, Chemical-Soil Map, and Soil Regionalization Map in the National Atlas of Vietnam). He also received numerous awards from the Academy, the Ministry, and the Committee on Science and Technology for his achievements in research on the natural environment of the country. He is Professor of Hanoi National University and Hanoi National University of Education. Prof. Pham has taught a number of courses in universities and institutes and has been scientific advisor of Ph.D. work of several students. He has been a member of editorial boards of four scientific magazines. Prof. Pham has nearly 100 works, including 7 monographs, textbooks, and tutorials published in Vietnamese, Russian, and English languages in 6 countries. 